第 1 表 反射波の数值計算例

\begin{tabular}{|c|c|c|c|c|}
\hline \multirow{2}{*}{ 諸 } & \multirow{2}{*}{ 記 号 } & \multicolumn{3}{|c|}{ 爆発の強さ } \\
\hline & & 強 & 中 & 弱 \\
\hline 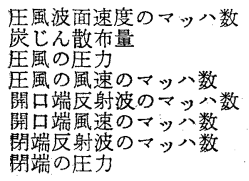 & $\begin{array}{c}M_{S} \\
d_{1} / \rho_{1} \\
P_{2} / P_{1} \\
u_{2} / a_{1} \\
M_{R E} \\
u_{5 R E} / a_{1} \\
M_{R S} \\
P_{5 R S} / a_{1}\end{array}$ & $\begin{array}{c}3.06 \\
0.20 \\
10.8 \\
2.27 \\
-0.07 \\
4.68 \\
1.24 \\
54.0\end{array}$ & $\begin{array}{l}1.65 \\
1.00 \\
3.01 \\
0.87 \\
0.53 \\
1.76 \\
0.96 \\
7.71\end{array}$ & $\begin{array}{l}1.20 \\
1.00 \\
1.51 \\
0.31 \\
0.83 \\
0.61 \\
0.96 \\
2.23\end{array}$ \\
\hline
\end{tabular}

いる。扣よその計算には, 坑道直径の 50 倍程度の距離 までは $\rho^{\prime}=1$ で実用的に鿁差が大きくないと考えられ る。

以上の計算方針にしたがつて, $P_{5 R S}, M_{R S}, u_{5 R E}, M_{R E}$ の値を求め第 1 表に示す。これ等の結果から次のような 推論ができる。

a）反射波がショックであつてもエクスパンションで めつても，それが爆発の火炎と行き会う場合にはその然 焼反応に大きな影響を与えると考えられる。したがつて 模型実験をする場合に，反射波と炎が行き会う点までで データを取るのが良かろう。特にエクスパンション反射 波では，消炎効果があることが予想される。

b) 弱い爆発程坑道端部から離れた点で反射波と炎が 行き会う。したがつて測定区間は坑道全長よりかなり短 かくなる。

c）開口端に圧風が来ると，風速は注涪 2 倍になる。
したがつて岩粉棚の動作の実験をするような場合に坑口 近くでするのは問題があるかも知れない。

d）爆発実験坑道を設計するに当つて，爆音による被 害を少なくするため，両端を閉した鉄管坑道にすること が考えられる。この時坑道に要求される強度が予想でき た。

e）強い爆発まで実験しょうとすれば，坑道の強度か ら，閉端の形にすることは無理のようである。また開口 端の場合は閉口端の場合に比しでつね反射波の速度が 遅いので，測定区間が長くとれる。また $d_{1} / \rho_{1}=0.2 \sim$ 1.0 で， $M_{S}>1.7 \sim 1.1$ では，開口端からの反射がまつ たくなくなり，坑口近くまで無限に長い坑道内と同じ現 象を示す。音の被害を除けば開口端が有利である。

f) 直径に比して長さが長い爆発実験で, 爆源から坑 道直径の $100 \sim 200$ 倍の距離までは, 炭じんを棚等に載 せて飛散し易くするか，ガス炭じん爆発にしなければ伝 ぱしにくい。それ以上の距離になると，床上に炭じんを 散布して打くだけで良いようである。

g）爆ごうの場合は圧風と炎が同時に到来するので, ここで考えたようなことは問題にならない。

数值計算をしたもののうち多くは実験で証明してない ので, 結果は定性的なきらいがある。しかしながら, 炭 じん爆発の実験計画をするのに参考になる多くの点が指 摘できたと思 万。特に大型爆発実験坑道の設計には役に 立つことが多かつた。

\title{
414 三池炭鉱三川坑における変質炭塵
}

$\begin{array}{rrrrr}\text { 九州工業大学教授・工博 } & \text { 荒 } & \text { 木 } & \text { 忍 } \\ \text { 早稲田大学理工学部教授・博 } & \text { ○房 } & \text { 村 } & \text { 信 } & \text { 雄 } \\ \text { 九州大学工学部助教授 } & \text { 柳 } & \text { 本 } & \text { 竹 } & \text { 一 }\end{array}$

昭和 38 年 11 月 9 日 15 時 12 分頃, 突然三池炭鉱三川坑第 一斜坑から火炎々黒煙を吹き出し, 死者 458 名, 負甥者 832 名を生ずる大爆発苂害が発生した。この苂害は我が 国に扣いては大正 3 年 12 月 15 日の方城炭鉱爆発（死者 687 名) に次ぐものであり，死者の数からみて世界第 5 位という規模であつた。

この災害に際しては監督官庁たる福榋鉱山保安監督局 が当初から総力をあげて救出・応急作業の指揮に当ると そもに原因究明に努めていたが，事の重大さに鑑み政府 灶臨時三池災害対策本部を現地に設置し，医療対策，遗 家族援護対策に当り，また原因究明のため技術調査団を 編成して現地に派遣することが決定された。調査団は 12 月13日から現地調查を行ない, 種々の資料にもとづいて 研究を重㸚，12月26日に一応の結論をうるに至つた。こ のように大きな爆発災害に際しては最終結論をうるまで には十二分の検討を要することは言うなでもない。現在 な打関係当局に打いて精密調査を続けているのも当然で 㐫了ら。

筆者らが坑内の爆発跡で採取した炭塵資料については 種々の角度から試験し観察を加えた結果は, 原因究明と いら線に直接の関係の有無は別として，それ自体注目す べき点も少なくないので，今までに調査した結果の概略 起述べて識者の批判を乞万次第である。
炭塵試料の採取，三川坑第一斜坑の坑口付近から斜坑 底まで調查当時接近しうる範冊内に扣いて $50 \sim 100 \mathrm{~m}$ 間 隔で, ベルトコンベヤのキヤリヤ脚の坑口側と卸側の付 着変質炭塺ならびにベルト上の堆積変質炭塵を採取し た。これから単位面積当り変質炭塵量を計算した。また 坑底付近のホッパ座に扣いて多量のコークス状変質炭塵 を発見した。坑口側と卸側の付着量は一般に有意の差が めり, 坑口から $1,620 \mathrm{~m}$ 付近を中心にして坑口側と卸側 との付着比が逆転していることがわかつた。推定計算の 結果によると, 第一斜坑全長を $2,100 \mathrm{~m}$, 坑道幅を $6,38 \mathrm{~m}$ として, 爆発後の坑道床面に打ける変質炭塵の堆積量は 約 $14.3 \mathrm{t}$ になる。

変質炭塵の分析, 変質炭麘と新鮮炭塵との工業分析值 を比較し, 揮発分, 固定炭素等の消費率を計算しょうと しても, 変質炭歴中に外来灰分 (坑道床面の岩石分) の 混大が多く成功しなかつた。変質炭塺を粒度別にわけ, それぞれについて比重分離を行なつた結果, 例えばキヤ リヤ脚の坑口側と卸側の変質炭框の差異を明確にするこ そができた。

これら調查例をグラフと写真で示せば次の通りであ る。

グラフは坑ロから $1,615 \mathrm{~m}$ 付近に批る変質炭塵の浮 沈分析結果である。試料 No. 33はキヤリヤ脚の坑口側, 


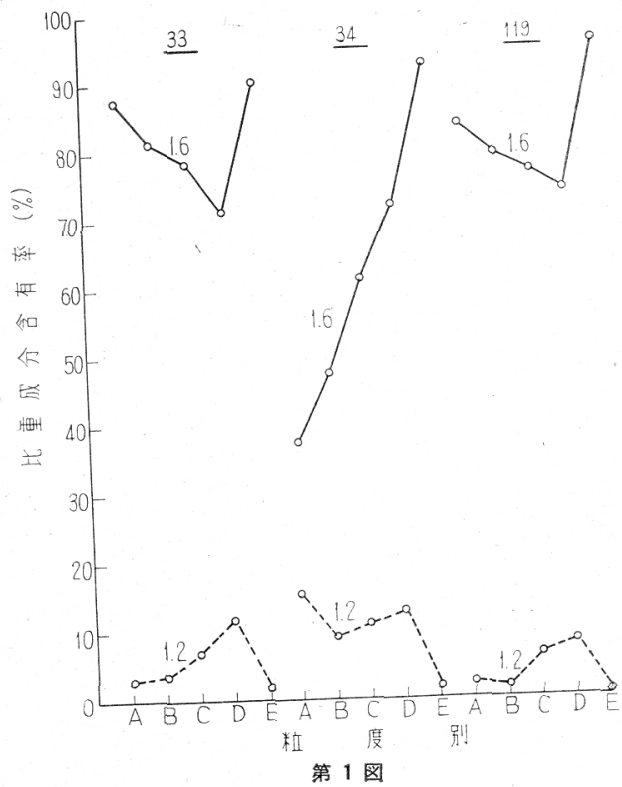

No. 34 は卸側, No. 119 はベルト表面の堆積試料でま る。試料は $\mathrm{A}=20 \sim 35 \mathrm{mesh}, \mathrm{B}=48 \sim 65$ mesh, $\mathrm{C}=$ 100 150mesh, $\mathrm{D}=200 \sim 270$ mesh, $\mathrm{E}=-270$ mesh 5 組に分け，重液で 1.6,1.4,1.3,1.2 および 1.2 以下 の 5 群に比電分離した。グラフからわかるように試料 No. 33 は試料 No. 119 と極めてよく類似していること がわかる。军真 $\mathrm{a}, \mathrm{b}, \mathrm{c}$ はそれぞれ試料 No. 33, 34 打上 び 119 の粒度 $48 \mathrm{mesh}$, 比重 1.6 成分の顕微鏡写真で ある。これによつて子陚料 No. 33 と No. 119 が非常 によく類似していることが明らかであるう。No.33 No. 119 の顕微鏡写真の黒色粒子は炭䵇, 白色粒子は岩 粉（防爆用の石灰岩粉ではなく夾炭層の砂岩）である。 これらの炭豎はむしろ膨張しているものが少ない。No. 34 の黑色粒子は汪とんどが膨張したり溶融した痕跡を 示している。そして岩粉の混入が少ないことが特徴にな つている。このような分析と㓋察を行なうことによつて 変質炭塵の特徴を明確にとらえることがでさる。なお， このほか変質孷塵について工業分析，分光分析およびX 線回折等を行なつた。

最低爆発濃度, 三川坑第一斜坑のベルトコンベヤ原動 機の冷却空気取入口にはェアフィルタが装備してあり， その内部には爆発の影響を受けていない、微細炭磨が存在 していた。これについて工業分析䘮行ない，計算によつ て最低爆発濃度を求めると, $117 \sim 125 \mathrm{~g} / \mathrm{m}^{3}$, 平均 121 $\mathrm{g} / \mathrm{m}^{3}$ といろ結果を得た。然料比 $0.73 \sim 1.79$ の九州崖 の最低爆発濃度が $75 \sim 270 \mathrm{~g} / \mathrm{m}^{3}$ であることからみて， この炭塵の危険度は低い汪らではないことがわかる。ま

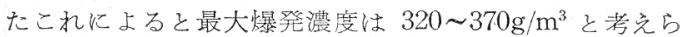
れる。

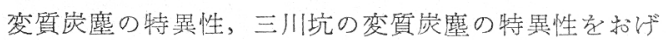
れば次の上うで岁る。

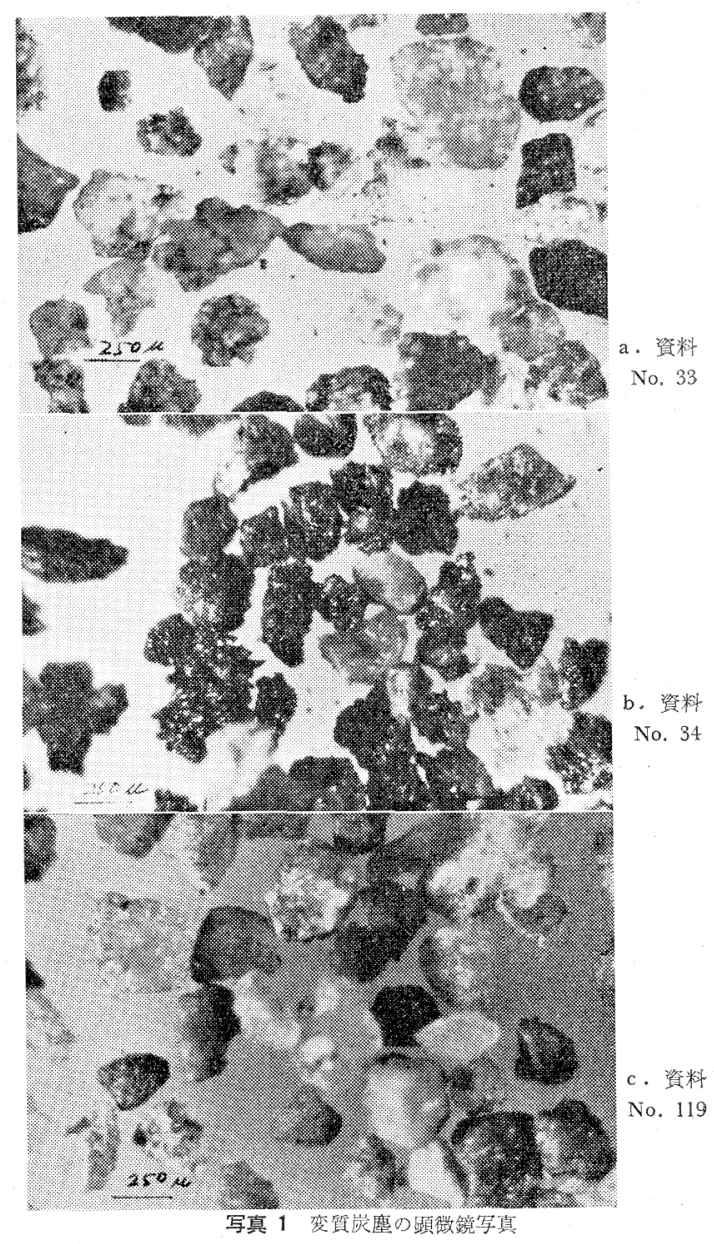

1) 第一斜坑に招いて坑底ホッ>゚付近除いては，ほ とんど肉眼で認められるようなコークス状変質炭塵は見 出し光なかつた。独立爆成球はホッ付近にの名存在し ていた。

2) 斜坑の一船の変質炭塺中の軽粒子（見掛比重 1.2 以下）はせいぜい1〜2\%であつたが，ホッパ付近の変 質炭魔中以はこれが $13 \sim 15 \%$ る市つた。

3）この上5に両者の浮沈分析值に大差が女るにも拘 らず，工業分析值の上では何れる灰分 50 60\% で有意 差を認め難かつた。

4）斜坑の変質炭麼には $200 \mathrm{mesh}$ 以下の微粒子を

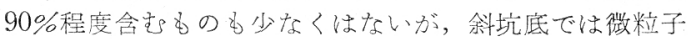
は $25 \%$ 以下である。

5）一般的飞みて斜坑部に見出された変質炭䖈は従来 の炭鉱爆発跡に見出されるるのとは著しく様相を異にし て和り，斜坑底部に見出されたるのは従来もしばしば見 出されたものに近い。 